\title{
CALCULATION OF PROBABILITY OF TRISO PARTICLE FAILURE USING TIMCOAT AND PEBBED CODE
}

\author{
Rokhmadi $^{1}$, Bebeh Wahid Nuryadin ${ }^{2}$, Khotib Maulani ${ }^{1,2}$, Topan Setiadipura ${ }^{1}$ \\ ${ }^{1}$ Center for Nuclear Reactor Technology and Safety-BATAN \\ PUSPIPTEK Area, Serpong, South Tangerang 15310, Indonesia \\ ${ }^{2}$ Department of Physics Faculty of Science and Technology-State Islamic University (UIN) Sunan \\ Gunung Djati Bandung, Jl. A.H Nasution 105, Bandung 40614, Indonesia \\ *email: rokh_rsg@batan.go.id
}

\begin{abstract}
CALCULATION OF PROBABILITY OF TRISO PARTICLE FAILURE USING

TIMCOAT AND PEBBED CODE. The calculation of the failure probability for fuel particles (TRISO) in the HTGR type reactor has been successfully carried out. This study aimed to estimate the failure probability of the fuel particles in the HTR-10 and HTR-PM, as well as to analyze the fuels of those reactors by varying the $\mathrm{SiC}$ thickness. The initial layer thickness of SiC in the HTR-10 and HTR-PM is $35 \mu \mathrm{m}$. The PEBBED code was used to simulate calculations resulting in the power distribution data, which is then compared with the results from the TIMCOAT simulation process. The TIMCOAT simulation calculation results, which are based on the SiC thickness variation, showed that the thickness failure is smaller if applied to the HTR-10 and HTR-PM. Based on the comparison between the two reactors, the failure probability of HTR-PM fuel particle has the value smaller than that of the HTR-10 with the difference of $10^{-5}$.
\end{abstract}

Keywords: failure particle, HTR-10, HTR-PM, TRISO, TIMCOAT.

\begin{abstract}
ABSTRAK
PERHITUNGAN PROBABILITAS KEGAGALAN PARTIKEL TRISO MENGGUNAKAN KODE TIMCOAT DAN PEBBED. Perhitungan probabilitas kegagalan untuk partikel bahan bakar (TRISO) di reaktor HTGR telah berhasil dilakukan. Penelitian ini bertujuan untuk memperkirakan probabilitas kegagalan partikel bahan bakar di HTR-10 dan HTR-PM, serta untuk menganalisis bahan bakar dari kedua reaktor tersebut dengan memvariasikan ketebalan SiC. Ketebalan awal lapisan SiC pada reaktor HTR-10 dan HTR-PM adalah $35 \mu \mathrm{m}$. Data distribusi daya yang diperoleh dari perhitungan simulasi menggunakan PEBBED kemudian dibandingkan dengan proses simulasi TIMCOAT. Hasil perhitungan simulasi TIMCOAT yang didasarkan pada variasi ketebalan SiC menunjukkan bahwa kegagalan ketebalan lebih kecil jika diterapkan pada HTR-10 dan HTR-PM. Berdasarkan perbandingan antara kedua reaktor, probabilitas kegagalan dari partikel bahan bakar HTR-PM memiliki nilai lebih kecil dari HTR-10 dengan selisih 10-5.
\end{abstract}

Kata kunci: kegagalan partikel, HTR-10, HTR-PM, TRISO, TIMCOAT. 


\section{INTRODUCTION}

Populations are now increasingly developing and innovating the knowledge and technology to make various kinds of automation tools that can make humans easier to carry out an activity. However, almost all of these tools use electricity as their main energy source. For this reason, Indonesia has used all potential sources in the world to produce electricity, from coal, wind, solar energies and maybe nuclear energy in the future. Furthermore, speaking of nuclear energy, nuclear power plants are one of the alternative electricity main producers. But due to a large amount of energy, nuclear energy may be classified as quite dangerous energy if applied for a nuclear bomb. It is evident from history that recorded several nuclear reactor accidents that occurred in several developing countries such as the Fukushima accident in Japan [1], Chernobyl in Russia [2] and Three Mile Islands (TMI) in USA [3]. Due to the previously mentioned taking place in several countries were certainly to highly motivate researchers to take lessons learned on nuclear reactor safety technology. It is then the nuclear producer researchers as well as Indonesia is now developing Gen IV reactors which will have an utmost of nuclear reactor safety and those are to be commercially operable in the 2030s.

Until now, High Temperature GasCooled Reactor (HTGR) has emerged and HTGR is a type of thermal helium cooled reactor that can produce heat up to $1000^{\circ} \mathrm{C}$ and hence the reactor can be applied not only to produce electricity but also to harvest hydrogen production, water desalination and coal liquefaction [4]. The reactor has inherent safety features and a passive technical safety system [5], so it has a much better level of safety and reliability. In addition, the reactor also has the ability to scram itself when the reactor has an accident and the remaining heat from the reactor will be released through air circulation. It is therefore, the HTGR has attracted to the nuclear community all over the globe since those are to be much safer, much more efficient, most environmentally friendly and have very high economic benefits [6].

In its development, HTGR has two fuel designs, namely the prismatic and pebble-bed types. HTGR uses nuclear fuel coated with a buffer layer and is coated by three structured layers and the fuel particles are named TRISO (TRIstructural ISOtropic) [7]. To simulate pebble-bed fuel particles, the TIMCOAT program was applied and before the appearance of the TIMCOAT program, 
there had been a previous program that looked similar to TIMCOAT called CRYSTAL (Code of Analysis of Stresses in coated particle).

Based on the decomposed background, the authors conducted a study on the TRISO fuel particle resistance test simulation to calculate the value of the failure. The reactor design used is the High Temperature Reactor 10 MWth (HTR-10) and High Temperature Reactor Pebble-Bed Modular (HTR-PM) which is operated by Tsinghua University, Beijing, China. Those types were chosen based on the design which is almost the same as the "Reaktor Daya Eksperimental" (RDE). The RDE is currently being developed by the National Nuclear Energy Agency (BATAN) and is expected that the simulation results can be contributed to the RDE detail design. The aim of this research is to analyze fuel particle failure of the HTR-10 and HTR-PM utilizing TIMCOAT and PEBBED codes. While the PEBBED code was used to develop modeling and core calculation, the TIMCOAT code was applied to estimate power distribution and homogeneous data.

\section{THEORY}

\section{Design of HTGR Pebble-Bed Safety}

High Temperature Gas-Cooled Reactor (HTGR) is a reactor capable of issuing higher temperatures than light water reactors (LWR) [8]. This reactor is an SMR (Small Medium Reactor) [8], which is capable of producing heat around $60{ }^{\circ} \mathrm{C}-1600{ }^{\circ} \mathrm{C}$. HTGR has two types of a fuel design that is the prismatic type and the pebble-bed type. In prismatic type, a number of TRISO particles are dispersed in cylindrical fuel elements which are inserted into a hexagonal graphite block [8]. As for the type of pebble-bed design, a number of fuel particles are dispersed into a spherical graphite matrix [8] commonly called pebble. Both types of fuel designs can be seen in Figures 1 and Figure 2.

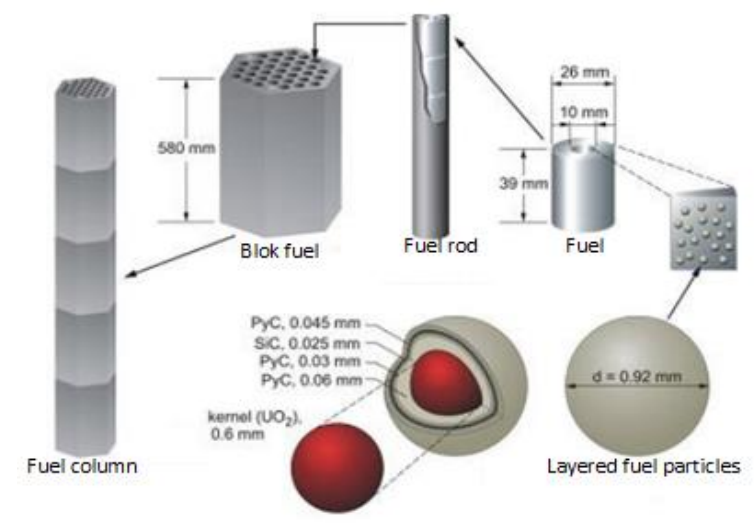

Figure 1. Schematic of prismatic type HTGR fuel [8]. 


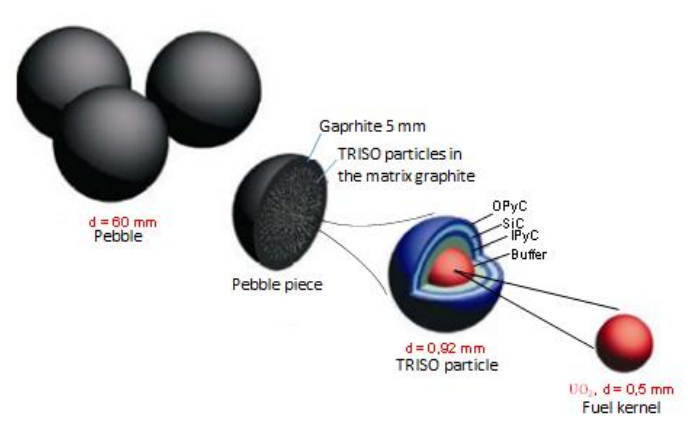

Figure 2. Schematic of pebble-bed type HTGR fuel [8].

\section{Experience of the HTGR Pebble-Bed}

\section{Design}

In its development, HTGR has two types of fuel design and of the pebblebed type fuel design was developed in several countries such as Germany and China. While the Pebble-bed reactor developed in Germany is named the Arbeitsgemeinschaft Versuch Reaktor (AVR) which has a power of 46 MWth in China, there is also a High Temperature Reactor 10 MWth (HTR10) that has a power of 10 MWth and High Temperature Reactor Pebble-Bed Modular (HTR-PM) which has a power of 400 MWth.

\section{Arbeitsgemeinschaft Versuch} Reactor (AVR) is a high temperature reactor that has a type of pebble-bed fuel design developed in Juelich, Germany. With an input temperature of $250^{\circ} \mathrm{C}$ and the resulting output temperature of 990 ${ }^{\circ} \mathrm{C}$, the reactor has a core height of $2.8 \mathrm{~m}$ and a diameter of $3 \mathrm{~m}$ and can accommodate around 100 pebbles and the AVR has been operating successfully for 21 years, from 1967 1988 in Juelich, Germany [9].

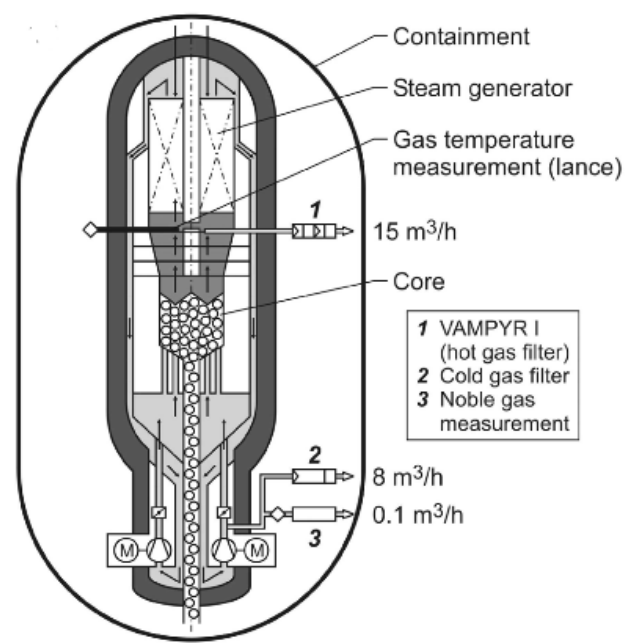

Figure 3. Schematic of AVR [9].

Table 1. Parameter of AVR [9].

\begin{tabular}{lcc}
\hline Parameter & Value & Unit \\
\hline Power & 46 & MWth \\
$\begin{array}{l}\text { Average power } \\
\text { density }\end{array}$ & 2.5 & $\mathrm{MW} / \mathrm{m}^{3}$ \\
$\begin{array}{l}\text { Reactor height } \\
\text { Reactor diameter }\end{array}$ & 2.8 & $\mathrm{~m}$ \\
$\begin{array}{l}\text { Cooler } \\
\text { Pressure }\end{array}$ & 3 & $\mathrm{~m}$ \\
$\begin{array}{l}\text { Helium inlet } \\
\text { temperature }\end{array}$ & 275 & Helium \\
$\begin{array}{l}\text { Helium outlet } \\
\text { temperature }\end{array}$ & $850-990$ & ${ }^{\circ} \mathrm{C}$ \\
Helium flow rate & $13-15.5$ & $\mathrm{~kg} / \mathrm{s}$ \\
\hline
\end{tabular}


High Temperature Reactor10 MWth (HTR-10) is a reactor that is oprated and developed by INET, Tsinghua University, Beijing, China. The HTR-10 has a core diameter of 1.8 $\mathrm{m}$ and a height of $1.97 \mathrm{~m}$ and has a reflector thickness of $100 \mathrm{~cm} \mathrm{[10].} \mathrm{The}$ core of the HTR-10 can accommodate 2,700 pebble fuel elements [11]. The scheme and parameters of the HTR-10 are deployed in Figure 4 and Table.2.

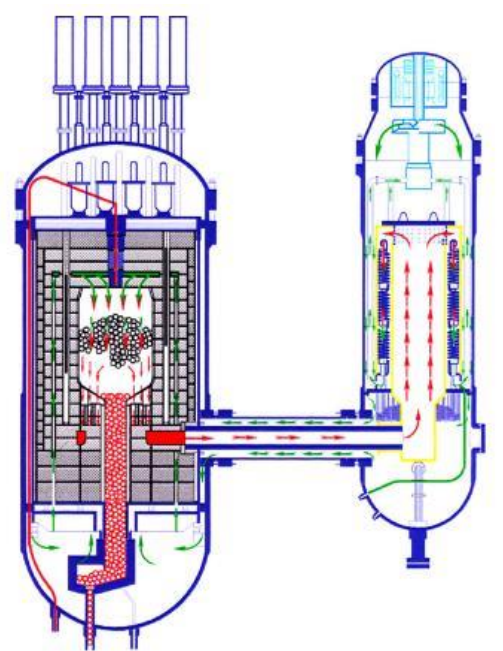

Figure 4. Schematic of HTR-10 [10]

Table 1. Parameter HTR-10 [10]

\begin{tabular}{lcc}
\hline \multicolumn{1}{c}{ Parameter } & Value & Unit \\
\hline Power & 10 & $\mathrm{MWth}$ \\
Pressure & 3 & $\mathrm{MPa}$ \\
Reactor diameter & 1.8 & $\mathrm{~m}$ \\
Reactor height & 1.97 & $\mathrm{~m}$ \\
Cooler & & Helium \\
Parameter & Value & Unit \\
Helium inlet temperature & 250 & ${ }^{\circ} \mathrm{C}$ \\
Helium outlet temperature & 700 & ${ }^{\circ} \mathrm{C}$ \\
Helium flow rate & 4.3 & $\mathrm{~kg} / \mathrm{s}$ \\
\hline
\end{tabular}

High Temperature Reactor PebbleBed Modular (HTR-PM) is reactor that was also developed by China and HTRPM is the development of the HTR-10 reactor. The reactor has an output power greater than HTR-10 which is equal to 400MWth and the reactor has a height of $24 \mathrm{~m}$ and a diameter of $6.7 \mathrm{~m} \mathrm{[12].}$

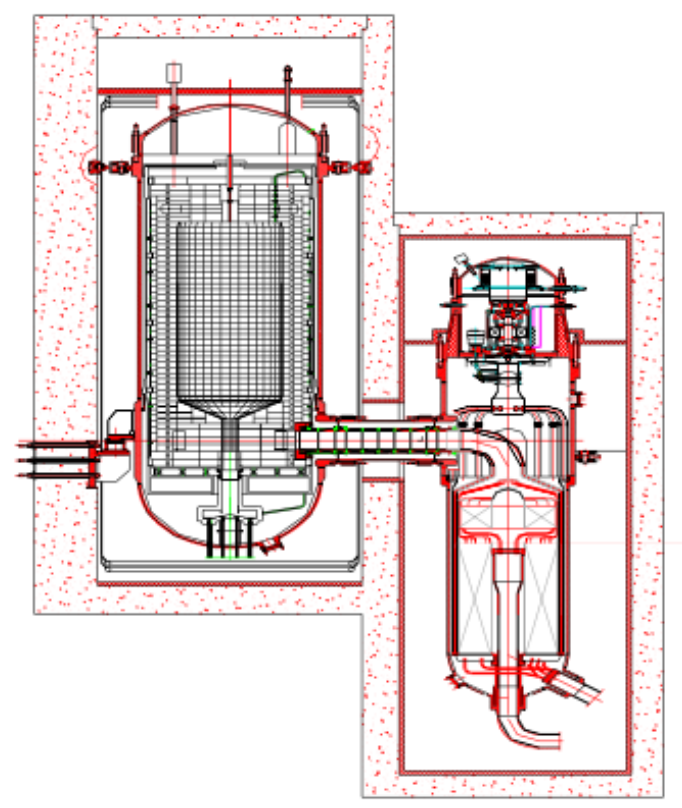

Figure 5. Schematic of HTR-PM [12].

Table 2. Parameter HTR-PM [12].

\begin{tabular}{lcc}
\hline \multicolumn{1}{c}{ Parameter } & Value & Unit \\
\hline Power & 458 & $\mathrm{MWth}$ \\
Pressure & 7 & $\mathrm{MPa}$ \\
Reactor diameter & 6.7 & $\mathrm{~m}$ \\
Reactor height & 24 & $\mathrm{~m}$ \\
Cooler & & Helium \\
Parameter & Value & Unit \\
Helium inlet temperature & 250 & ${ }^{\circ} \mathrm{C}$ \\
Helium outlet temperature & 750 & ${ }^{\circ} \mathrm{C}$ \\
Helium flow rate & 176 & $\mathrm{~kg} / \mathrm{s}$ \\
\hline
\end{tabular}




\section{Fuel Design of Pebble-Bed Reactor}

The fuel in HTGR is layered fuel particles called TRISO (TRI-structural ISOtropic) [7] and especially for pebblebed type reactor designs, a number of layered fuel particles are dispersed in spherical graphite material with a diameter of $6 \mathrm{~cm}$ and the ball is called "pebble". Overall the pebble is composed of graphite material as a moderator made to resemble a ball shape with a diameter of $6 \mathrm{~cm}$ and containing layered fuel particles of approximately 15,000 particles [13]. TRISO particles are arranged from the kernel as center of fuel coated with a buffer layer made from material PyC (pyrolytic carbon) and then coated with three structural layers. These layers are the IPyC layer (inner pyrolytic carbon), the $\mathrm{SiC}$ layer (silicon carbide) and the $\mathrm{OPyC}$ layer (outer pyrolytic carbon).

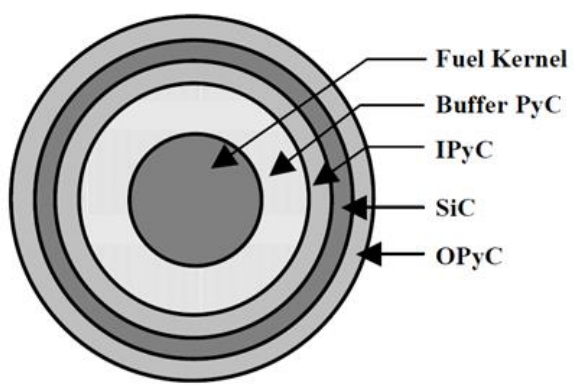

Figure 6. Schematic of particle layer [14].

The kernel is the center of the fuel particles which are generally in the form of Uranium Oxide, Thorium or
Plutonium, and kernels have relatively small sizes of approximately 300-600 $\mu \mathrm{m}$ [13]. For the oxide-based kernel, when the reactor is operating a certain amount of oxygen will be released by the kernel prodused by the fission reaction. The oxygen produced will interact with the PyC layer to produce carbon monoxide which will move to the cold side of the kernel. Causing the kernel move to the hot side. If it continues, the kernel will push the PyC layer and tear it up to the $\mathrm{SiC}$ layer. This will affect the performance of the $\mathrm{SiC}$ layer and can cause particle failure. This failure is called the amoeba effect or kernel migration [6]. The buffer layer is a layer that is in direct contact with the kernel and this layer is composed of porous pyrolytic carbon material so that it has a low density of around $0.9-1.1$ $\mathrm{gr} / \mathrm{cm}^{3}$ [13] and has a thickness of approximately $90 \mu \mathrm{m}$. Because of its nature, this layer has three main functions, namely reducing the adverse effects of fission products, as an empty volume and as a protector for three structural layers [15]. The IPyC layer is the first layer of three structured layers and this layer is composed of pyrolytic carbon material which has a density of about $1.8-2.0 \mathrm{gr} / \mathrm{cm}^{3}$ [13] and a thickness of approximately $40 \mu \mathrm{m}$. In general, this layer has a function to 
protect the SiC layer and the followings are the four main functions of the IPyC layer, protecting the fuel kernel from chlorine compounds $(\mathrm{HCl})$, helping to smooth the surface of the $\mathrm{SiC}$ layer during the $\mathrm{SiC}$ coating process, inhibiting fission product travel to the $\mathrm{SiC}$ layer, reducing stress on the $\mathrm{SiC}$ layer [15]. The SiC layer is the second layer of three structural layers which has a density of about $3.20 \mathrm{gr} / \mathrm{cm}^{3}$ [13]. The $\mathrm{SiC}$ layer has two main functions, as a vessel to accommodate the release of fission gas from within and as a major barrier to the fission products produced by the kernel [15]. When this layer is damaged or failed, it can be ascertained that the fuel particles have failed and cannot be reinserted into the reactor core. The SiC layer cannot survive when the reactor's operating temperature exceeds the normal limit or more than $1600^{\circ} \mathrm{C}[13]$. The $\mathrm{OPyC}$ layer is the last layer of the fuel particle and just like the buffer layer and the IPyC layer, this layer is composed of pyrolytic carbon material. This layer has several functions, as the final barrier for fission products produced by the fuel particle kernel, as a protective $\mathrm{SiC}$ layer before the irradiation process, adapting the $\mathrm{SiC}$ layer during the irradiation process and blocking the $\mathrm{SiC}$ layer from external chemical reactions [15].

\section{METHODOLOGY}

The research was conducted at the Center for Nuclear Reactor Technology and Safety - BATAN Serpong, South Tangerang. The method carried out in this research is a simulation of testing high temperature reactor fuel with a pebble-bed type fuel design using code TIMCOAT. The stages carried out in this study are as follows:

1. To study literature on hightemperature reactors with the design of pebble-bed type fuel, specifically about pebble-bed reactor fuel particle failure.

2. To arrange the parameters of both reactors (HTR-10 and HTR-PM).

3. To determine the number of particle samples to be tested.

4. To review simulation and research results.

5. To apply TIMCOAT for analysis simulation of fuel failure in the HTR-10 and HTR-PM

6. To discuss and analyze the simulation results. 


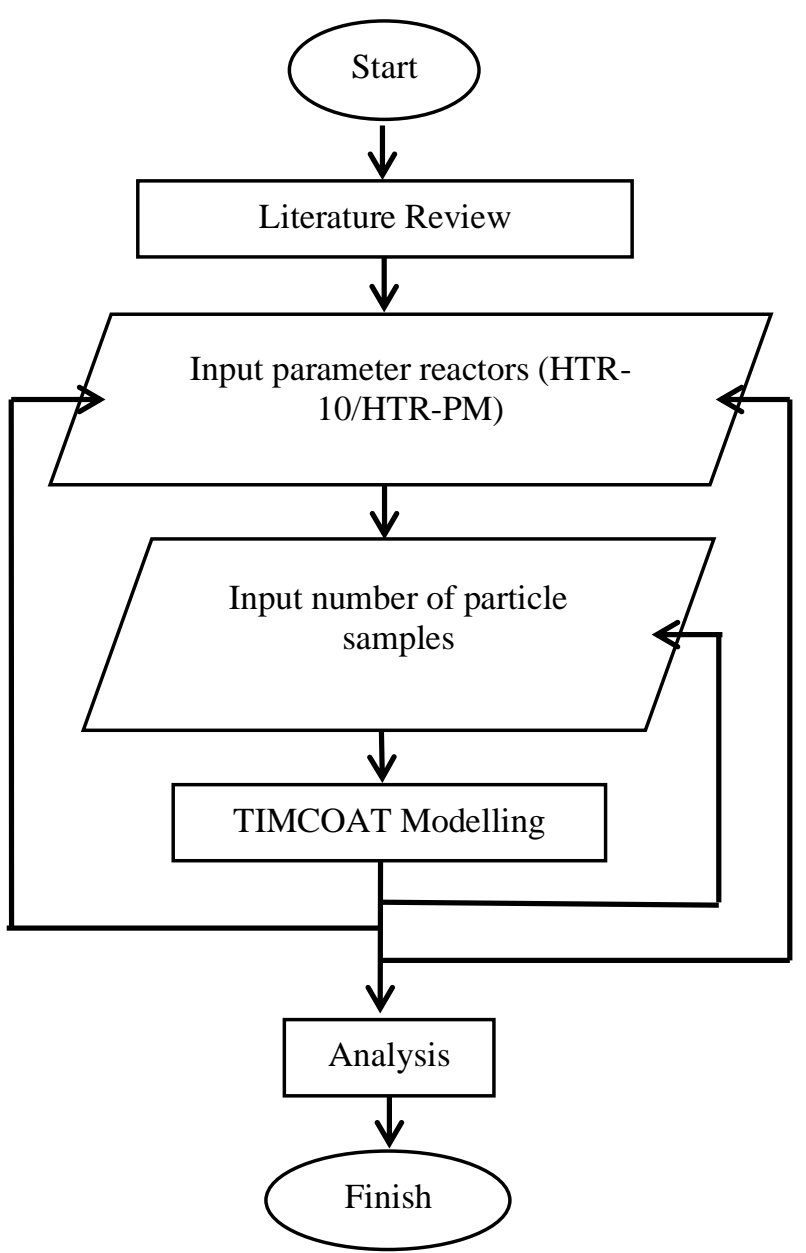

Figure 7. Schematic of flowchart of the study [6].

The Integrated Model of COATED (TIMCOAT) is a program from Fortran that implements the performance of fuel from a high temperature reactor with a pebble-bed type particle fuel design. TIMCOAT simulates fuel particles when starting to enter on the reactor-bed terrace until it exits the terrace. The power distribution at TIMCOAT is obtained from an external source. The homogeneous TIMCOAT program gets the data from the VSOP program. When the program is run, the program directly enters data on power distribution and flux distribution. After that, the program will randomly select samples of a fuel particle on a pebble and the speed of the pebble. The power density and flux distribution are also determined. Particles will be analyzed in terms of mechanics and chemical aspects. If the particle fails or the $\mathrm{SiC}$ layer is damaged, the program will randomly look for other fuel particle samples. If the particle does not fail, then the fuel particles will be seen whether or not they are still on the terrace. If the particles have not come out from the terrace, then the particle must have a new position on the terrace. The program will repeat the stages of determining power distribution and flux distribution at different intervals. If the particle has come out from the terrace, the program will repeat and try a different pebble flow with the same particle. And if the fuel gets out of the back terrace without damage, the next program will try with different particles.

\section{RESULTS AND DISCUSSION}

\section{Comparison Analysis}

Comparisons were made to the HTR-10 and HTR-PM reactors to 
determine the performance of the two reactors which were essentially the same.

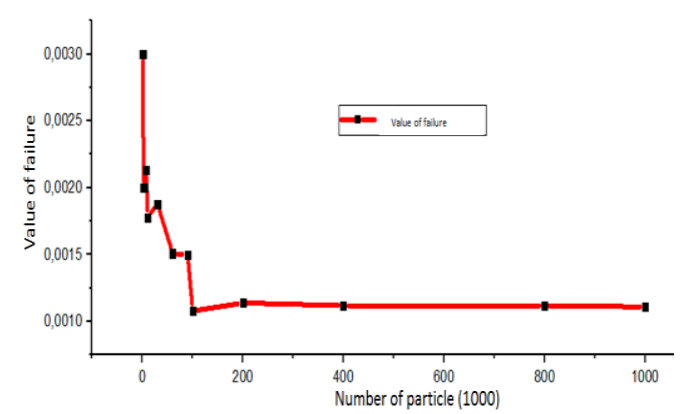

Figure 8. Graph of value of failure for number particle of HTR-10.

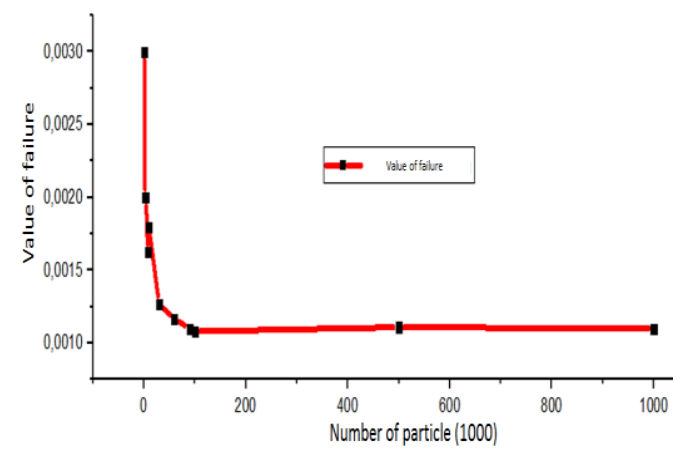

Figure 9. Graph of value of failure for number of particles of HTR-PM.

Figures 8 and Figure 9 show a graph of particle failure values for the number of particles tested at the HTR-10 and HTRPM reactors. Figure 9 shows the results of the calculation for the value of failure of the HTR-10 at $1.8 \times 10^{-3}$, while that of the HTR-PM is $1.1 \times 10^{-3}$. By comparing these two values, HTR-PM has a failure value smaller than HTR-10. This is because the HTR-PM is a patented HTR-10 reactor and has been used for commercial purposes. For this reason, HTR-PM has a big size and the output power is greater than the HTR-10, almost 15 times.

\section{Failure Fuel Particle Analysis}

Fuel particle failure takes place due to so many factors that can affect fuel particles when the reactor operates. Because of this, the role of each layer of particles is needed. The following image in the form of a graph of fuel particle failure correlates to the number of particles tested.

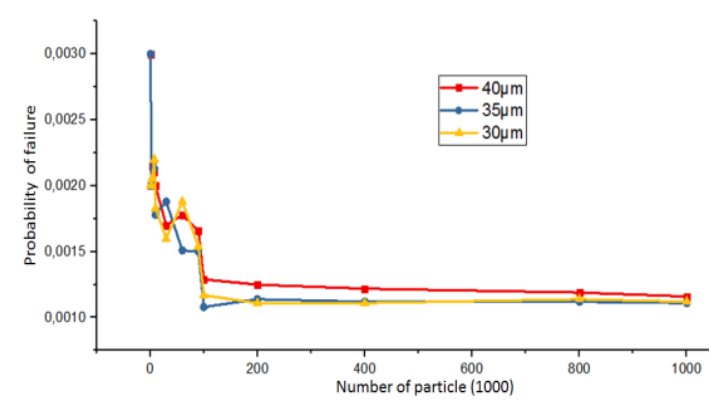

Figure 10. Graph probability of failure for number of particle of HTR-10 fuel particle failure for the number of particles tested.

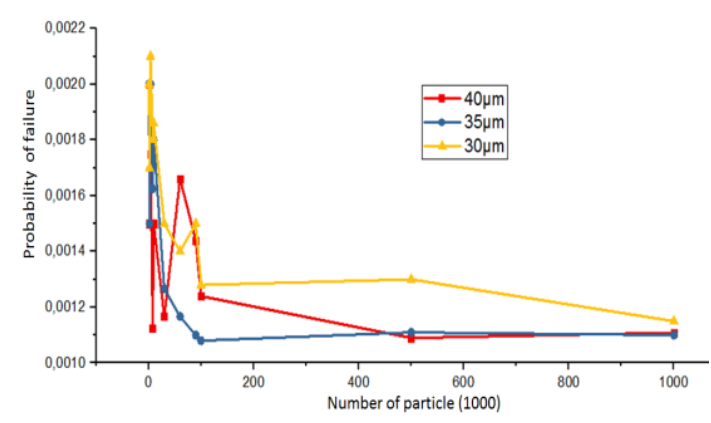

Figure 11. Graph of HTR-PM fuel particle failure for the number of particles tested. 
Table 4. Data on fuel particle failure by varying the thickness of the $\mathrm{SiC}$ layer.

\begin{tabular}{ccc}
\hline $\begin{array}{c}\mathrm{SiC} \\
\text { layer } \\
(\mu \mathrm{m})\end{array}$ & $\begin{array}{c}\text { Particle failure at } \\
\text { HTR-10 }\end{array}$ & $\begin{array}{c}\text { Particle failure } \\
\text { at HTR-PM }\end{array}$ \\
\hline 30 & $1.12 \mathrm{E}-03$ & $1.109 \mathrm{E}-03$ \\
35 & $1.11 \mathrm{E}-03$ & $1.1 \mathrm{E}-03$ \\
40 & $1.16 \mathrm{E}-03$ & $1.15 \mathrm{E}-03$ \\
\hline
\end{tabular}

The table and figure above are calculation results of fuel particle failure in the HTR-10 and HTR-PM by varying the SiC layer. In the HTR-10 the smallest value of fuel particle failure was found in the $\mathrm{SiC}$ layer with a thickness of $35 \mu \mathrm{m}$, as well as in the HTR-PM the smallest particle fuel failure value was obtained with a $\mathrm{SiC}$ layer thickness of $35 \mu \mathrm{m}$.

\section{Fuel Particle Kernel Analysis}

For fuel kernels made from oxide, when the reactor operates with a temperature gradient above $1000^{\circ} \mathrm{C}$, the kernel will produce oxygen. The oxygen produced will react with $\mathrm{PyC}$ to form carbon monoxide and carbon monoxide formed will move to the cold side of the particle, thus pushing the kernel to the hot side of the particle [16]. If it continues, the kernel will push the buffer layer and tear it and this type of failure is called the amoeba effect [15]. Xenon and krypton produced from fission and carbon monoxide gas formed from the reaction of $\mathrm{PyC}$ and oxygen (derived from fission gas) will fill the pore space in the buffer layer. Together with this, the fuel kernel will experience swelling due to precipitation from fission (gas and solid). The empty volume in the buffer layer will decrease as the volume of the fuel kernel increases. This condition can cause an increase in gas pressure in fuel particles [16]. In general, the reactor with a prismatic type of fuel design will often experience an amoeba effect problem, due to the prismatic reactor having a higher power density compared to the pebble-bed reactor [15].

\section{Buffer Layer Analysis}

Each layer of fuel particles has a role to play in maintaining the performance of the fuel particles. The fuel cell center or kernel is protected by a buffer layer before being coated with three structured layers. The buffer layer is a porous layer and has a small density so that it can absorb the elements released by the kernel and can withstand the pressure exerted by gases resulting from fission. The buffer layer is an important layer for protecting three layers structured and protects the performance of the fuel particles. When the kernel swells because irradiation, the buffer layer will provide extra volume 
for the fuel particle. Generally, the buffer layer has a larger layer than the other layers. If the buffer layer is too thin or eliminated, the internal pressure will increase dramatically and cause premature failure. Conversely, if the buffer layer is too thick it will cause temperature rise in the kernel because the buffer layer has a lower thermal conductivity compared to the other layers [15]. When the reactor operates, the kernel will emit highspeed fission products so that the fission product has great kinetic energy. Even so, the fission product will bump and bounce several times with the closest material so that it releases some of its energy and slows down its speed. When the speed of the fission product slows down, the buffer layer can easily absorb the fission product. In addition, the gases from fission products are able to provide pressure to the structural layer, therefore the buffer layer has the task of stabilizing the pressure. Conditions in the buffer layer when the reactor operates, are not taken into account and even if the buffer layer has great shrinkage and severe cracks [15].

\section{IPyC Layer Analysis}

The IPyC layer is able to protect the kernel from chlorine compounds used during the $\mathrm{SiC}$ coating process. When the particle coating process by the $\mathrm{SiC}$ layer, chlorine compounds are used during the process. The chlorine can enter and react with the uranium kernel. Chlorine that reacts with uranium can create other fission products that can damage the layers of fuel particles. The IPyC layer is able to make the surface of the $\mathrm{SiC}$ layer flat and smooth that the buffer layer cannot do because the buffer layer has low of density properties and is too fragile. Because the layer if the $\mathrm{SiC}$ layer is uneven and smooth, the performance of the $\mathrm{SiC}$ layer will not be complete [15]. The IPyC layer can hold most of the fission gas products, especially carbon monoxide $(\mathrm{CO})$, which can attack the $\mathrm{SiC}$ layer when the temperature rises.

\section{SiC Layer Analysis}

The $\mathrm{SiC}$ layer is chosen as the layer varied because the $\mathrm{SiC}$ layer can hold the radiation produced and released by the kernel particles [14]. So when the $\mathrm{SiC}$ layer is damaged, then the particle can be directly said to fail. However, the $\mathrm{SiC}$ layer requires help from the buffer layer and two other structural layers. Exposure from fast neutron will shrink the IPyC and OPyC layers. Because the $\mathrm{SiC}$ and PyC layers (IPyC and OPyC) have strong bonds, the $\mathrm{SiC}$ layer will experience compressive stress by the 
PyC layer. On the other side, the pressure in the particles will cause tensile stress on the $\mathrm{SiC}$ layer, so this can reduce the compressive stress from the inside particle [16]. The $\mathrm{SiC}$ layer will work very well when the temperature is less than $1000{ }^{\circ} \mathrm{C}$, when the temperature rises to more than 1250 ${ }^{\circ} \mathrm{C}$, the fission product is a palladium element and lanthanide elements such as cesium and strontium begin to attack the $\mathrm{SiC}$ layer. When the temperature reaches $1600{ }^{\circ} \mathrm{C}$, the kernel will emit palladium, the element will react with the $\mathrm{SiC}$ layer and make the $\mathrm{SiC}$ layer corrosion. In addition, when the temperature is between $1600{ }^{\circ} \mathrm{C}-1800{ }^{\circ} \mathrm{C}$, the silver element can emerge from the $\mathrm{SiC}$ layer through micro of cracks in the SiC layer. When the temperature reaches more than $2000{ }^{\circ} \mathrm{C}$, the $\mathrm{SiC}$ layer will decompose and lose its integrity. Therefore a high temperature reactor with a pebble-bed type fuel design limits the temperature when operating only $1300{ }^{\circ} \mathrm{C}$ to $1600^{\circ} \mathrm{C}$ [15].

\section{OpyC Layer Analysis}

For the OPyC layer, this layer has properties similar to the IPyC layer and the layer has a function to protect the $\mathrm{SiC}$ layer from outside interference. In addition, the OPyC layer is also able to protect the $\mathrm{SiC}$ layer when the pebble formation process is likely to disrupt the $\mathrm{SiC}$ layer and prevent unexpected chemical reactions that can occur and affect the SiC layer. Failure does not only occurs when the reactor operates, failure can also occur when coating the fuel particles with graphite to form a pebble ball.

\section{Accident Analysis}

When an accident occurs various kinds of things can happen that affect the fuel particles. The insertion of reactivity and the entry of water and oxygen are two things that generally occur that result from accidents. Generally, fuel particles can hold energy in the range of $1000-2000 \mathrm{~J} / \mathrm{gr}$ and during an accident, sudden deposition of energy will cause a number of cases such as overheating and excessive pressure which cause particle failure. When particles reach energy higher than $1000-2000 \mathrm{~J} / \mathrm{gr}$, this can damage the fuel kernel. When accidents, water and air (especially oxygen) can enter the main system through cooling loops and can come into contact with fuel particles. When the temperature is high, the water will not dissolve the PyC layer too much. But the oxygen that enters can react with PyC, so that water can expose the kernel from fuel particles to the environment along with the fission 
products that were previously held back [16].

\section{CONCLUSION}

The process of failure in fuel particles can occur by various things. Not only by internal factors caused by fission reactions, but it could also be due to external factors such as failure that occur during the process of making these particles and during the process of making pebble. Even though the SiC layer is the most important layer, in fact all three layers are needed for fuel particle perfomance. Based on the comparison of the value of failure between the HTR-10 and HTR-PM reactors, the HTR-PM has a smaller particle failure value than the failure value of the HTR-10 and hence the HTR-PM reactor should be used for commercial matters.

\section{RECOMMENDATION}

In this study, the TIMCOAT program was used to calculate the value of failure fuel particle in the HTR-10 and HTR-PM reactors, with power distribution data obtained in the PEBBED program. For further research, it is expected to be able to continue the calculation of the value of failure of the two reactors, by increasing variations in the thickness of the silicon carbide layer.

\section{ACKNOWLEDGMENT}

The author is very appreciative to Dr. Geni Rina Sunaryo, the Director of Center for Nuclear Reactor Technology and Safety (PTKRN-BATAN) and Dr. R. Muhammad Subekti, head of Reactor Technology Safety Division, who have encouraged the completion of this paper. Secondly, the author thanks to the Physics Department of State Islamic University (UIN) Bandung, which collaborated its students in this research to complete their studies.

\section{REFERENCES}

[1] P. UDIYANI, S. KUNTJORO, AND J. SITORUS, "Analisis Kecelakaan Parah Pada Pressurized Water Reactor dengan Backward Method," J. Teknol. Reakt. Nukl., vol. 15, no. 1, 2013.

[2] Z. ALATAS, "Konsekuensi Kecelakaan Reaktor Chernobyl Terhadap Kesehatan Dan Lingkungan," Bul. Al., vol. 7, no. April, pp. 79-87, 2006.

[3] G. SUHARIYONO, "Perkembangan tenaga nuklir di dunia," Bul. Al., vol. 7, no. April, pp. 102-112, 2006. 
[4] S. M. LUMBANRAJA, "Studi Reaktor Temperatur Tinggi PBMR - Perkembangan teknologi dan prospek reaktor temperatur tinggi PBMR perlu dikajl di Indonesia . Konsep PBMR \{ Pebble Bed Modular Reactor ) dikembangkan berdasarkan tekonologi reaktor U235 diperkaya antara 8-10\%, terd," J. Pengemb. Energi Nukl., vol. 9, no. Reaktor Temperatur Tinggi PBMR, pp. 29-37, 2007.

[5] T. SETIADIPURA, "Requirements of Pebble Bed Reactor ' s Plant Information Model Center for Nuclear Reactor Technology and Safety Introduction," no. June, 2015.

[6] J. WANG, “An Integrated Performance Model for High Temperature Gas Cooled Reactor Coated Particle Fuel by," 2004.

[7] P. DEMANGE, J. MARIAN, M. CARO, AND A. CARO, “TRISOfuel element thermo-mechanical performance modeling for the hybrid LIFE engine with $\mathrm{Pu}$ fuel blanket," J. Nucl. Mater., vol. 405, no. 2, pp. 144-155, 2010.

[8] S. ALIMAH, E. DEWITA, AND S. ARIYANTO, "Analisis Komparasi HTGR Tipe Prismatik dan Pebble Bed," J. Pengemb. Energi Nukl., vol. 16, no. Juni, pp.
11-21, 2014.

[9] R. THEENHAUS AND S. STORCH, "The AVR HighTemperature Reactor-Operator Experience, Storage and Final Disposal of Spent Fuel Elements." pp. 681-684.

[10] F. AZIZ AND A. N. LASMAN, "Analisis Pasca-Kritikalitas Pertama Reaktor Temperatur Tinggi HTR-10 China," LKSTN XII, Juli, 2001.

[11] Z. WU, D. LIN, AND D. ZHONG, "The design features of the HTR10," Nucl. Eng. Des., vol. 218, no. 1-3, pp. 25-32, 2002.

[12] Z. ZHANG, Z. WU, Y. SUN, AND F. LI, "Design aspects of the Chinese modular high-temperature gas-cooled reactor HTR-PM," Nucl. Eng. Des., vol. 236, no. 5-6, pp. 485-490, 2006.

[13] M. A. STAWICKI, R. G. BALLINGER， A. C. KADAK, AND J. A. CODERRE, "Benchmarking of the MIT High Temperature Gas-Cooled Reactor TRISO-Coated Particle Fuel Performance Model by," no. March, 2006.

[14] J. WANG, R. G. BALLINGER, H. J. MACLEAN, AND J. T. DIECKER, "Timcoat: an Integrated Fuel Performancemodel 
for Coated Particle Fuel," Nucl.

Technol., vol. 148, no. 1, pp. 1-45, 2004.

[15] C. SOONTRAPA, "Design Optimization and Analysis of Coated Paticle Fuel Using Advanced Fuel Performance Modeling Techniques," pp. 1-154, 2006.

[16] B. HERUTOMO, "Analisis Keandalan bahan bakar reaktor tempera tur tinggi," Pros. Semin. Ke-5 Reakt. Temp. Tinggi, pp. 117-131, 2000. 